\title{
Yenilenebilir Enerjide Teknoloji Analizi
}

\author{
Yunus Emre Özdemir ${ }^{1 *}$, Metin Yavuz ${ }^{2}$ \\ 1* Ondokuz Mayıs Üniversitesi, Lisansüstü Eğitim Enstitüsü, Yenilenebilir Enerji ve Uygulamaları, Samsun, Türkiye, (ORCID: 0000-0003-0379-5278), \\ yunusemreozdemir@hotmail.com \\ ${ }^{2}$ Ondokuz Mayıs Üniversitesi, Fen Edebiyat Fakültesi, Fizik Bölümü, Samsun, Türkiye (ORCID: 0000-0002-1262-9135), myavuz@omu.edu.tr
}

(International Symposium on Multidisciplinary Studies and Innovative Technologies (ISMSIT) 2021 - 21-23 October 2021)

(DOI: 10.31590/ejosat.1023124)

ATIF/REFERENCE: Özdemir, Y. E. \& Yavuz, M. (2021). Yenilenebilir Enerjide Teknoloji Kapsam Analizi. Avrupa Bilim ve Teknoloji Dergisi, (29), 138-143.

\section{Öz}

Patentler; yeni yatırımlar, araştırmalar ve ticari kararlar almada dinamik araç olarak kullanılma imkanına sahiptir. Teknoloji analizleri nitel ve nicel yaklaşımlarla teknolojiyi analiz etmek olarak geçmektedir. Bu çalışmada, Orbit yazılımları kullanılarak yenilebilir enerjide Dünya-Türkiye karşılaştırmalı nicel Teknoloji Analizi yapılmıştır. Bu analiz ile patent aktivitesi, başvuru ve patent sahipleri, pazar büyüklükleri, anahtar kelime kullanarak teknoloji alanlarının tespiti ve bilimsel etkinliklerin analizi gibi veriler incelenmiş ve sunulmuştur. Çin'in yenilenebilir enerji alanındaki patent sayılarında bariz bir şekilde üstün olduğu hatta bu alanda kendisini takip eden 5 ülkenin toplamından daha fazla patent ürettiği görülmektedir. Dünya'da yenilenebilir enerji alanındaki teknolojilerde ana uygulama alanları elektrik makineleri, aparatlar, enerji, motorlar, pompalar, türbinler ve isıl işlemler ve aparatlar şeklinde sıralanırken, Türkiye'de ise motorlar, pompalar, türbinler, elektrik makinaları, aparatlar, enerji şeklinde sıralanmaktadır. Kullanılan yazılım ile yapılan "Renewable Energy" aramasında yenilenebilir enerji alanındaki buluşların, akademik çalışmaların durumunun ne olduğu, teknolojilerin nerelere yoğunlaştığı ve hangi yeni teknolojinin hangi alanlara yöneldiği analiz edilmiştir. Bu analizler ile Türkiye'nin yenilenebilir enerji alanında yatırım doygunluğuna ulaşmamış olduğu görülmüştür.

Anahtar Kelimeler: Sürdürülebilir enerji, Yeşil enerji, Yenilenebilir kaynaklar, Rüzgâr enerjisi, Yenilenebilir elektrik, Biyokütle enerjisi, Güneş paneli, Güneş enerjisi, Rüzgâr türbini, Hidroelektrik santral, Yenilenebilir enerji.

\section{Tecnology Analysis in Renewable Energy}

\begin{abstract}
Patents; It has the opportunity to be used as a dynamic tool in making new investments, research and commercial decisions. Technology analyzes are referred to as analyzing technology with qualitative and quantitative approaches. In this study, World-Turkey comparative quantitative Technology Analysis in renewable energy was performed using Orbit software. With this analysis, data such as patent activity, applicants and patent holders, market sizes, identification of technology areas using keywords and analysis of scientific activities were examined and presented. It is seen that China is clearly superior in the number of patents in the field of renewable energy, and even produces more patents in this field than the sum of the 5 countries that follow it. While the main application areas in renewable energy technologies in the world are electric machines, apparatus, energy, motors, pumps, turbines and heat treatments and apparatus, in Turkey, motors, pumps, turbines, electrical machines, apparatuses, energy are listed as. In the search for "Renewable Energy" with the software used, it was analyzed what the innovations in the field of renewable energy, the status of academic studies, where the technologies are concentrated and which new technologies are directed to which areas. With these analyzes, it has been seen that Turkey has not reached investment saturation in the field of renewable energy.
\end{abstract}

Keywords: Sustainable energy, Green energy, Renewable source, Wind energy, Renewable electricity, Biomass energy, Solar cell, Solar energy, Wind türbine, Hydroelectric power plant, Geothermal energy, Technoloy landscape analysis, Renewable energy.

\footnotetext{
* Sorumlu Yazar: Ondokuz Mayıs Üniversitesi, Lisansüstü Eğitim Enstitüsü, Yenilenebilir Enerji ve Uygulamaları, Samsun, Türkiye (ORCID: 00000003-0379-5278), yunusemreozdemir@hotmail.com
} 


\section{Giriş}

Bilgi-ekonomisinin temelini inovasyon oluşturmaktadır. İnovasyon ise genellikle patent/faydalı model olarak korunmaktadır. Patentler bilimsel bilgileri barındırdığından, bu alandaki çalışmaların en önemli göstergelerinden bir tanesidir. Patentler nitel veya nicel ticari faaliyetlerin oluşumunu, etki alanını, gideceği yeni alanları bize gösterir.

Teknoloji kimi zaman ihtiyaçları yönlendiren bunu toplumda ihtiyaç oluşturan bir derleme, ürün, bilimsel çalışmalar iken kimi zaman da ihtiyaçlar doğrultusunda oluşan toplumsal değişimin öncüsüdür. Bundan dolayı teknoloji anlamak, gelişimini yönünü tahmin etmek, buna bağlı olarak rekabet gücünü en üstün tutmak için bazı analiz yöntemleri mevcuttur. Teknoloji analizleri ("Technolgy Landscape", "Patent Trend Analizi" gibi isimleri olmakla beraber bu çalışmada Teknoloji Analizi olarak bahsedilecektir) birçok farklı metot ile yapılabilmektedir. Teknoloji öngörüsü; Delphi, TRIZ, zaman serileri, trend analizleri, simülasyon modelleri, bilimsel literatür analizleri, regresyon analizleri ve istatistik gibi nitel ve nicel metodolojilerle yapılabilmektedir (Jun, S. 2015; Hua, Yang, \& Coulibaly, 2006; Rowe \& Wright, 2001; Liimatainen, vd. 2014; Woudenberg, 1991; Liang,Tan, \& Ma, 2008; Mitchell, 1992; Kabataş \& Akgün, 2020 ).

Teknoloji analizi için çoğu nitel yöntem uzmanların hedef teknoloji hakkındaki bilgisine dayanmaktadır. Bunlar, alan uzmanlarının çeşitli deneyimlerinden getirildikleri için öznel olabilir. Dolayısıyla niteliksel yaklaşımların performansı teknoloji uzmanı tarafindan dalgalanabilir. Teknoloji analizinin diğer bir yaklaşımını nicel metodolojiye dayanmaktadır. Bunlar kümleme, Bayesian ve regresyon gibi istatiksel analiz yöntemlerini dikkate almaktadır (Jun \& Lee, 2013; Jun \& Park, 2012).

Ayrica, nitel metodolojide uzman bilgisi yerine teknoloji analizi için patent belgeleri kullanılmaktadır. Büyük veri tekniklerinin gelişmesiyle birlikte nicel teknoloji analizi ile ilgili araştırmalar son yıllarda hızla artmaktadır (Jun, 2015).

Patentler ticari açıdan o kadar önemli hale gelmiştir ki şirketler ve ülkeler için bu alanlardaki gelişmeleri takip edebilmek için ticari yazılımlar da geliştirilmektedir. Bu ticari yazılımlar nitel analiz yaparak gelişmeleri istatistiki metotlar ve grafiklerle sunarak öngörüde bulunabilmekte, yönlendirme açısından adeta karar destek sistemi olarak çalışabilmekte ve mevcut durumu analiz edebilmektedir.

\section{Materyal ve Metot}

Teknoloji Analizi, Orbit Innovation yazılımı kullanılarak yapilmıştır.

Bu program ile patent aktivitesi, başvuru ve patent sahipleri, pazar büyüklükleri, anahtar kelime kullanarak teknoloji alanlarının tespiti, bilimsel etkinliklerin analizi gibi verilere erişilebilmektedir. Bu veriler aşağıdaki gibi açıklanabilir:

Patent aktivitesi ile; yenilenebilir enerji alanındaki teknolojilerde patentlere bağlı trend durumu sorgulanabilmektedir. Bu kısımda, son 20 yılda başvurulan patent ve faydalı modeller analiz edilerek oluşturulmuş veriler kullanılmıştır. Burada yıllara göre ülkelerin aldıkları patentleri gösteren grafikler ile hangi ülkelerin öne çıtığını gösteren şemalar yer almaktadır.

$\mathrm{Bu}$ bilgiler ile sektördeki yatırımların devam edip etmediği ve hangi ülkelerin bu alanda daha aktif çalıştığı bilgilerine erişim sağlanabilmektedir.

Başvuru ve patent sahipleri verisi ile; bu alandaki yapılan başvuru sayılarına göre başvuru sahiplerini grafik olarak gösterebilmektedir.

Pazar büyüklüklerini gösteren veriler ile; bu alanda çalışan firmalar ve ekipler tarafindan üretilen harcama hacmi, pazarın yoğunluğunun ve doygunluğunun bir ölçüsü görülebilmektedir.

Anahtar kelime kullanılarak teknoloji alanlarının tespitinden elde edilen veriler ile; yenilenebilir enerji alanındaki patentlerde bulunan en yaygın anahtar kelimeleri analiz ederek, en ana akım teknolojiler görülebilmektedir. Buradaki etiketler, patentlerin tam metinlerindeki en yaygın 10 kavramın çıarılması ile hesaplanmaktadır. Patent istemlerinde yer alıyorsa belirli kavramlara daha güçlü bir ağırlık verilmektedir.

Bilimsel etkinlik verileri ile; makaleler içerisinde yenilebilir enerjinin hangi bilimsel alanlarda kullanıldı̆̆ını göstermektedir. Burada, makalenin yayınlandığı yer makalenin kaynağını gösteremediği için ülke bazlı veri yerine tüm Dünya'yı gösteren veriler yer almaktadır.

\section{Araştırma Sonuçları ve Tartışma}

\subsection{Yenilenebilir Enerjide Teknoloji Analizi}

Günümüzde sıkça karşımıza çıkan yenilenebilir enerji kavramı enerjinin fosil kaynaklar yerine doğal kaynaklardan elde edilmesi ile ortaya çıkmıştır.

Enerji kaynakları yenilenebilir enerji ve yenilenemeyen enerji olarak kullanışlarına göre ayrılmaktadır.

Yenilenemeyen enerji kaynakları fosil kaynaklardır. Bu kaynaklar petrol, kömür, doğalgaz gibi kaynaklardır. Yenilenebilir enerji kaynakları ise, tükenmeyen ve kullanıldıkça da eksilmeyen kaynaklardır. $\mathrm{Bu}$ kaynaklar hidrolik enerji, güneş enerjisi, biyokütle enerjisi, rüzgar enerjisi, dalga enerjisi ve jeotermal enerji kaynaklarıdır (Kaya \& Koç, 2015).

Günümüzde çok fazla kullanılan yenilenemeyen enerji kaynakları günden güne azalmakta ve gelecekte de hem doğaya verdiği zararlar hem de tükenmesi nedeniyle kullanılamayacaktır. Bu nedenle yenilenebilir enerji kaynaklarının önemi günden güne artmaktadir.

Bu önem artmasını günümüzde de oldukça görüyoruz. Ulusal ve uluslararası oldukça fazla firma ve üniversite bu alanda araştırmalar ve geliştirmeler yapmakta ve bu alandaki çalışmalara katkı sağlamaktadır.

Yenilenebilir enerji alanındaki çalışmalar ve yatırımlar; artan enerji ihtiyac1, teknolojideki yeni gelişmeler, fosil enerji türlerinin çevreye olumsuz zararları nedeniyle artmaktadır. Bu konuda teknoloji analizi yapmak hem teknolojiyi yakından takip etmek hem de yapılacak çalışmalara yol gösterici olup çalışılan alanın doğru tespiti ile gerekli alanlara yatırım yapmayı kolaylaştırmaktadır.

$\mathrm{Bu}$ çalışmada, yenilenebilir enerjinin Dünya'da ve Türkiye'de patent başvuruları, araştırmalar bazında nereye yöneldiği analiz edilmiştir. Gerekli yerlerde karşılaştırmalı olarak verilen bu analizler aynı zamanda hangi alanlarda daha çok 
buluşlar getirdiğini de göstermektedir. $\mathrm{Bu}$ alana yatırım yapacaklar için aynı zamanda adeta bir yol haritası da oluşturmaktadır.

Popüler araştırmalara baktığımızda, bilim ve teknoloji patentlerinde yer alan bilgilerin yaklaşık \%80'inin başka bir yerde yayınlanmadığını göstermektedir. Yayınlanan patentlere bakıldığında bu bilgilerin halkın incelemesi amacıyla başvuru dokümanlarında yayınlandığını görüyoruz. Bu bilgilerin direkt kullanması da mümkün olabilmekte ancak verilerin topluca incelenip analiz edelerek karar vermede kullanılabilecek şekilde sunulacak çıtı olarak kullanıma sunulabilir (Aggarwal \& Chandra, 2021).

Çalışmamızda, Orbit yazılımları kullanılarak yapılan "Renewable Energy"aramasında yenilenebilir enerji alanındaki buluşların, akademik çalışmaların vb. çalışmaların durumunun ne olduğu, teknolojilerin nerelere yoğunlaştığı ve hangi yeni teknolojinin hangi alanlara yöneldiği analiz edilmiştir. Alt arama başlıkları olarak ise sustainable energy (sürdürülebilir enerji), green energy(yeşil enerji), renewable source(yenilenebilir kaynaklar), wind energy(rüzgar enerjisi), renewable electricity(yenilenebilir elektrik), biomass energy(biyokütle enerjisi), solar cell(güneş paneli), solar energy(güneş enerjisi), wind türbine(rüzgar türbini), hydroelectric power plant(hidroelektrik santral), geothermal energy(jeotermal enerji) girilerek spesifikleştirilerek sonuca daha doğru verilerle ulaşılmak istenmiştir.

Teknoloji analizi yapılırken son 2 yıllık patent başvuruları tescil edilmemiş olabileceğinden bu veriler genellikle göz önünde bulundurulmadan tahmin yapılmaktadır.

\section{a. Patent Aktivitesi}

\section{i. Dünya'daki Patentler}

Dünya'da yenilenebilir enerji alanındaki patent sayılarında hemen hemen her geçen yıl artış olduğu Şekil 1'de görülmektedir. Grafikte de görüldüğü üzere 2015-2018 yıllarına baktığımızda \%10 civarı bir artış ile Dünya'daki başvuruların günümüzde de giderek arttığı görülmektedir.

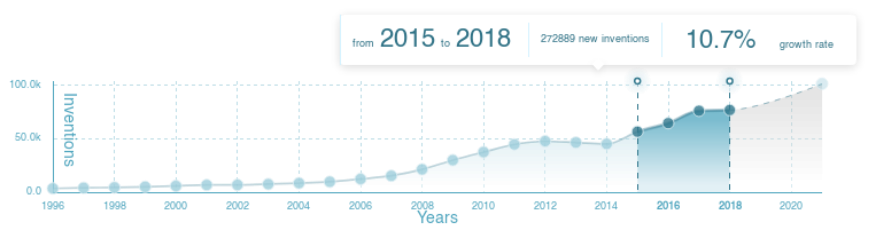

\section{Şekil 1 Dünya'daki Yenilenebilir Enerji Alanındaki Yıllara Göre Patent Saylarl \\ Kaynak: Orbit Innovation}

\section{ii. Türkiye'deki Patentler}

Türkiye'de yenilenebilir enerji alanındaki patent sayıları incelendiğinde, Şekil 2'de görüldüğü üzere patent sayılarının az olması nedeniyle net bir artış ya da azalıştan söz etmek mümkün değildir. $\mathrm{Bu}$ nedenle, az sayıdaki patent değişimin büyük dalgalanmalara neden olduğu grafikten görünmektedir. Burada da 2015-2018 arasındaki veriler incelendiğinde \%42'lik bir düşüş görülmektedir. Böylece, Türkiye'deki patent sayılarını Dünya'daki sayılarla karşılaştırdığımızda, Dünya'nın oldukça gerisinde olduğunu ve bu alana ağırlık vermesi gerektiği sonucunu çıkarabiliriz.

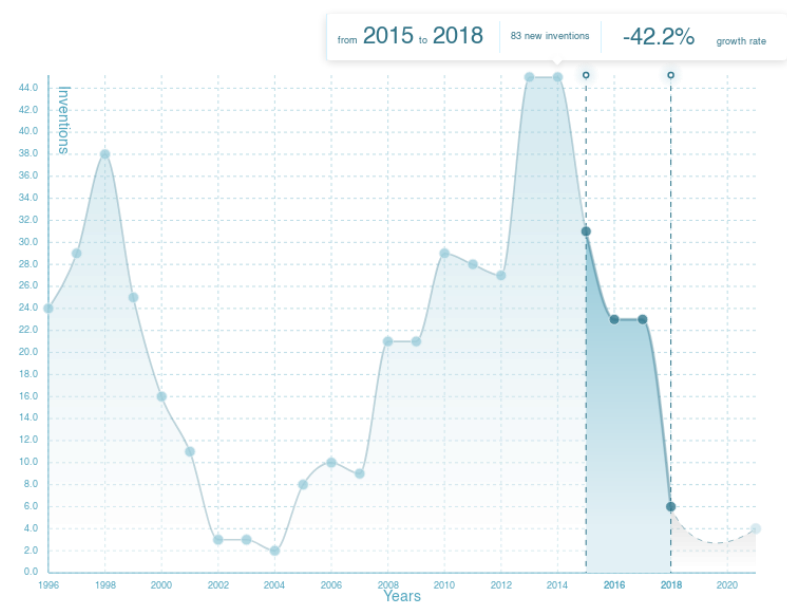

\section{Şekil 2 Türkiye'deki Yenilenebilir Enerji Alanındaki Patent Sayları \\ Kaynak: Orbit Innovation}

Grafiğe bakıldığında; 1998 yılından sonra 2002-2004 arasındaki patent sayılarındaki azalma dramatik seviyelere ulaştıktan sonra 2004 yılından itibaren tekrar patent sayılarında artış olduğu görülmektedir. Bu dönemde yüksek öğretim ve kamunun Ar-Ge harcamalarında kayda değer bir azalma olmadığı bilakis bu harcamaların arttığı görülürken özel sektör Ar-Ge harcamalarında bir miktar azalma görülmektedir (Tubitak Ar-Ge Harcamaları, 2021; Tunç, H. 2008). Özel sektördeki bu azalma 2001 krizi ile bağlantılı olabilir. Özel sektördeki bu azalma 2003 y1lı itibariyle son bulmuş ve bu durum da grafikte görülen Türkiye'de yenilenebilir enerji alanındaki patent sayılarıyla paralellik göstermektedir. Yüksek öğretim ve kamu kurumlarındaki Ar-Ge harcamalarının artması ise yenilenebilir enerji alanında patent çıktısı olarak yansımadığı şeklinde de yorumlanabilir.

2008 Küresel ekonomik krizinin ise hem Türkiye hem de Dünya'daki yenilenebilir enerji alanındaki patent sayılarına direkt bir etkisi görülmemektedir.

\section{b. Coğrafi Durum}

Grafik, son 10 y1l içerisinde ülkelere göre korunan patentlerin hacmini göstermektedir. Şekil 3'te, yenilenebilir enerji alanında Çin'in bariz bir üstünlüğü görünmektedir. Çin'in kendisini takip eden 5 ülke kadar patent üretmiştir. Çin'i patent sayılarında Japonya ve ABD takip etmektedir. Çin'in bu patent sayılarına yenilenebilir enerjinin yayılmasını teşvik etmek için 2006 yılında çıkardığı "Yenilenebilir Enerji Kanunu" ile başlattığı yatırım seferberliği sürecinin sonunda ulaştığı söylenebilir. Çin, bu modeli Almanya'dan almıştır ve daha ileri bir seviyeye taşımıştır. Çin'in yenilenebilir enerji modeli içerisindeki; tarife garantisi sistemi, enerji portfolyo sistemi, finansal sübvansiyonlar, vergi teşvikleri, kota uygulamaları ve yeşil sertifika sistemi ile ülkenin yenilenebilir enerji kurulu güç kapasitesi önemli ölçüde arttırılmıştır. 2018 yılı verilerine göre Çin'in toplam yenilenebilir enerji kurulu kapasitesi içerisinde rüzgâr ve güneş enerjisinin oranı \% 49,8 oranındadır. Bu orandan Çin'in modern yenilenebilir enerji yatırımları alanında ne kadar ileri gittiği açık bir şekilde görülmektedir (Kaya \& Bayraktar, 2019). 


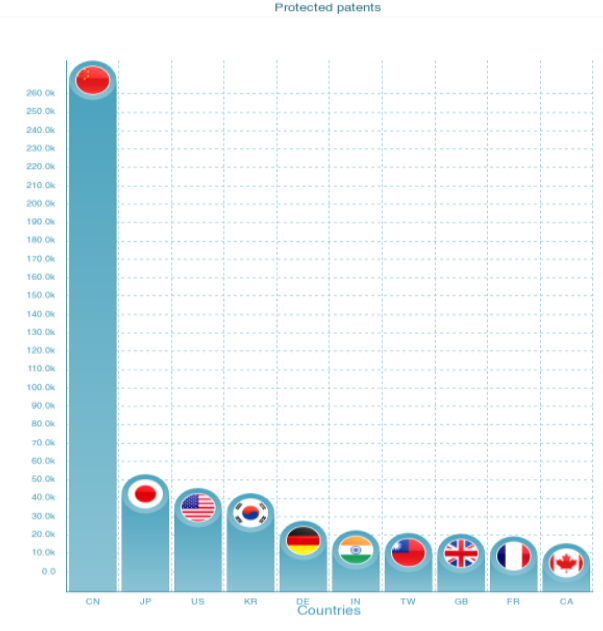

Şekil 3 Ülkelere Göre Korunan Patent Sayllar Kaynak: Orbit Innovation

\section{c. Fikri Haklar Alanındaki Başvuru Sahipleri}

Bu konuda Dünya'daki oyunculara baktığımızda aşağıdaki grafik oraya çıkmaktadır. Şekil 4'teki grafikte 6340 icattan oluşan portföyü ile yenilenebilir enerji alanındaki ana oyuncu State Grid Corporation of China (SGCC)'dir. Diğer 3 ana oyucunuyla birlikte ilk 100'ün \%13.05'ini temsil etmektedir.

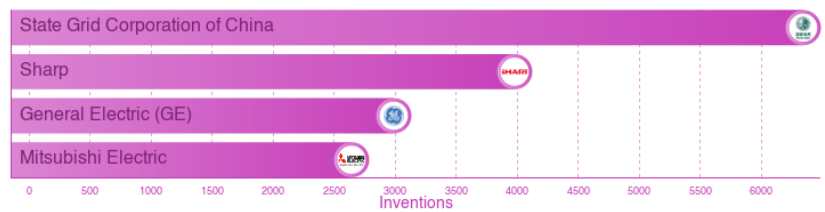

Şekil 4 Fikri Haklar Alanındaki Başvuru Sahipleri Kaynak: Orbit Innovation

\section{d. Pazar}

\section{i. Dünya'daki Yenilenebilir Enerji Harcama Hacmi}

Şekil 5'te Dünya'daki yenilenebilir enerji harcamaları grafiği görülmektedir. Dünya'daki Yapay Zeka buluşlarının üretim hacmi 6.1 milyar dolar seviyesindeyken Yenilenebilir Enerji 8.4 milyar dolar seviyelerindedir.

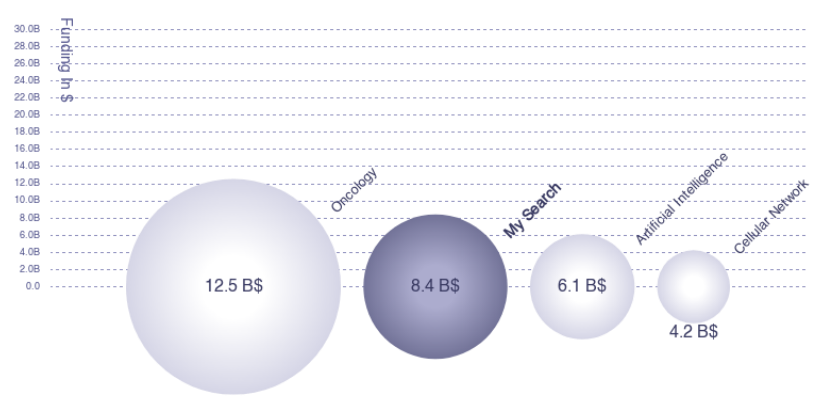

Şekil 5 Dünya'daki Yenilenebilir Enerji Harcama Hacmi Kaynak: Orbit Innovation

\section{ii. Türkiye'deki Yenilenebilir Enerji Harcama Hacmi}

Şekil 6'da ise Türkiye'deki yenilenebilir enerji harcama hacmi görülmektedir. Yine aynı şekilde burada Dünya'daki Yapay Zeka buluşlarının üretim hacmi 6.1 milyar dolar seviyesindeyken Türkiye'deki Yenilenebilir Enerji 70.3 milyon dolar seviyelerindedir. Şekil 5 ve Şekil 6 karşılaştırıldığında ise Türkiye'nin Pazar payının ne kadar az olduğu görülmektedir.

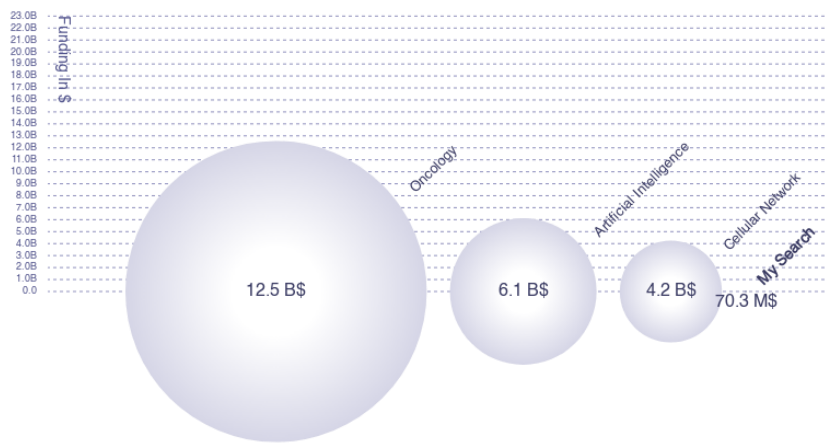

Şekil 6 Türkiye'deki Yenilenebilir Enerji Harcama Hacmi Kaynak: Orbit Innovation

\section{e. Anahtar Kelime Analizi}

\section{i. Dünya'daki Patentlerin Anahtar Kelime Analizi}

Şekil 7'deki grafikten de görüleceği üzere dünyada en fazla yoğunlaşma yenilenebilir enerji alanındaki patentlerde yenilenebilir enerji kelime öbeğinde olmaktadır. İkinci olarak solar panel üçüncü olarak solar enerji şeklinde devam etmektedir. Aşağıdaki tabloda da bazılarının sayıları yer almaktadır.

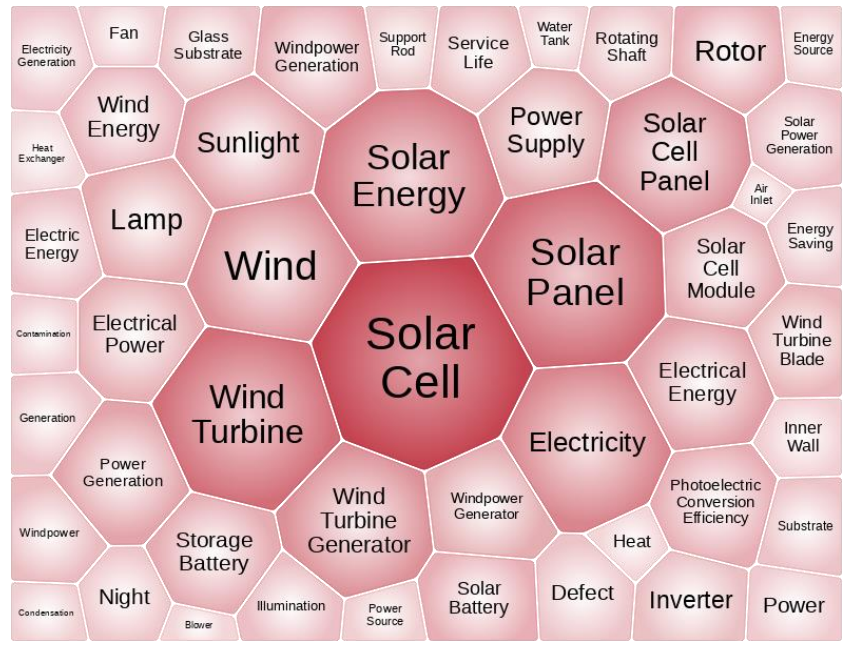

Şekil 7 Dünya'daki Patentlerin Anahtar Kelime Analizi Kaynak: Orbit Innovation

\section{ii. Türkiye'deki Patentlerin Anahtar Kelime Analizi}

Şekil 8'deki grafikten görüleceği üzere ise Türkiye'de en fazla yoğunlaşma yenilenebilir enerji alanındaki patentlerde rüzgar türbini kelime öbeğinde olmaktadır. İkinci olarak solar cell üçüncü olarak water şeklinde devam etmektedir. Aşağıdaki 
tabloda da bazılarının sayıları yer almaktadır.

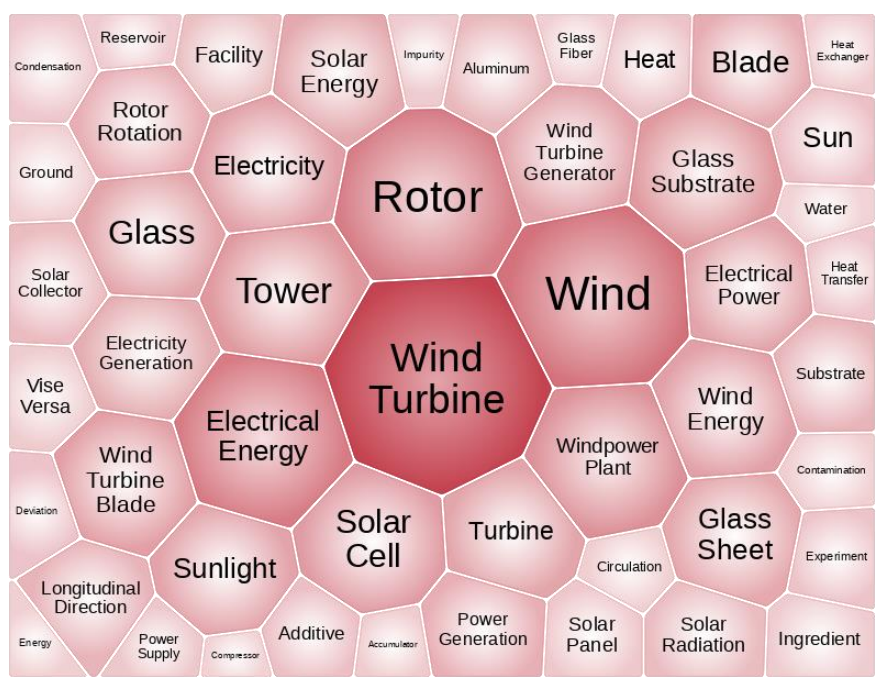

Şekil 8 Türkiye'deki Patentlerin Anahtar Kelime Analizi Kaynak: Orbit Innovation

\section{f. Teknoloji Alanları}

\section{i. Dünya'daki Ana Teknoloji Alanları}

Yenilenebilir enerji alanındaki teknolojinin Dünya'daki ana uygulamaları Elektrik Makinaları, Aparatlar, Enerji, Motorlar, Pompalar, Türbinler ve Isıl İşlemler ve Aparatlardır.

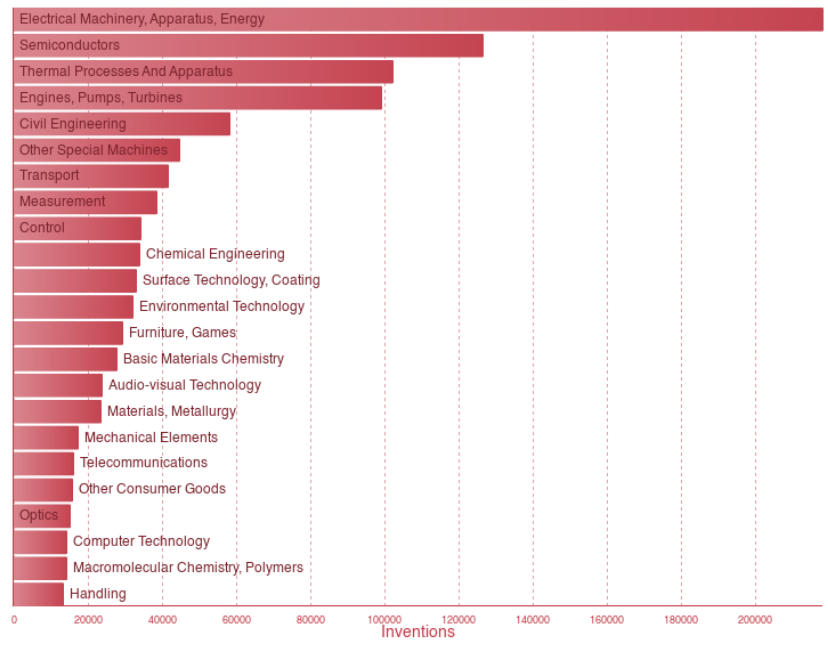

Şekil 9 Dünya'daki Ana Teknoloji Alanlarl Kaynak: Orbit Innovation

\section{ii. Türkiye'deki Ana Teknoloji Alanları}

Yenilenebilir Enerji alanındaki teknoloji Türkiye'nin ana uygulamaları ise Şekil 10'daki grafikte görülmektedir. Motorlar, Pompalar, Türbinler, Elektrik Makinaları, Aparatlar, Enerji şeklinde devam etmektedir.

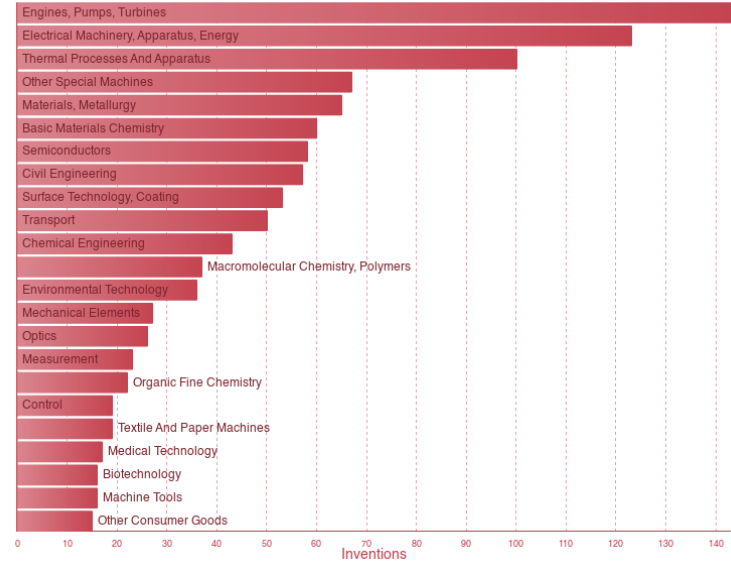

\section{Şekil 10 Türkiye'deki Ana Teknoloji Alanlart Kaynak: Orbit Innovation}

\section{g. Bilimsel Etkinlik}

Şekil 11'deki grafikte görüldüğü üzere bilimsel çalışmalardaki Yenilenebilir Enerji ile ilgili en çok Mühendislik alanında çalışmalar yapılmışken onu Kimya Bilimi, Malzeme, Elektronik takip etmektedir.

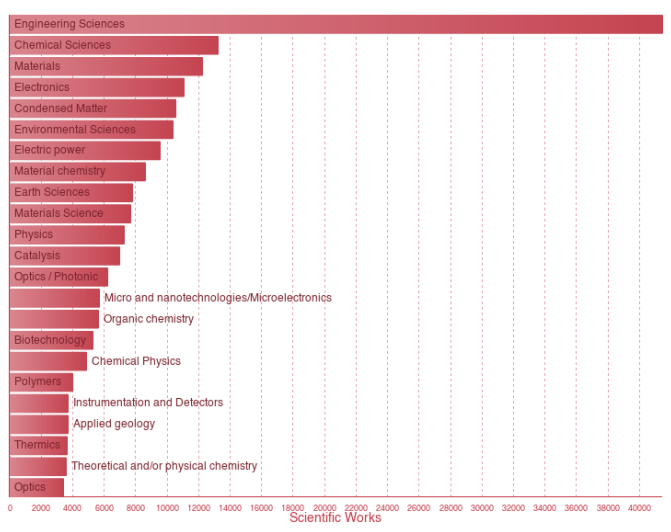

\section{Şekil 11 Bütün Bilimsel Çallşmalardaki Bilimsel Alanlar Kaynak: Orbit Innovation}

\section{Sonuç}

Günümüzde hangi alanda yatırım yapılacağı ve bu trendin nereye meylettiğini tahmin edebilmek bu çalışmaları yapmak kadar önemli olmaktadır. Çünkü, teknoloji bir tarafa giderken enerjiyi yanlış alanlara harcamak zaman ve para kaybına neden olabilmektedir.

Türkiye güneş, rüzgar, dalga, jeotermal, hidroelektrik enerjileri konusunda oldukça zengin bir ülkedir. Patent sayılarına baktığımızda, Türkiye'nin yenilenebilir enerji alanında son 20 yılda Dünya'nın 10binde 3'ü kadar patenti vardır. Dünya'da yenilenebilir enerji alanında en çok patenti olan ülkelere baktığımızda ise Çin'in açık ara önde olduğu görülmektedir. Bu sonuçla aynı zamanda yenilenebilir enerji alanındaki başvurularda liderliği çeken şirketin Çin'li State Grid Corporation of Chine olması şaşırtmamaktadır. Pazar büyüklüklerine baktığımızda da Türkiye'de 70.3 milyon dolar ile bu alana yatırım yapılabilir olduğu anlaşılmaktadır.

Anahtar kelime ve teknoloji alanları analizi kısmında 
Dünya'daki ve Türkiye'deki Patentlerin anahtar kelime analizleri incelenmiş ve Dünya'daki patentlerde en fazla Solar Panel ve Solar Energy geçerken Türkiye'deki patentlerde en fazla Wind Turbin anahtar kelimesi geçmektedir. Yenilenebilir Enerjinin uygulama alanlarına baktığımızda ise Dünya'da en fazla Elektrik Makineleri, Aparatlar, Enerji iken Türkiye'de Motorlar, Pompalar ve Türbinler biçiminde sıralanmaktadır. Bilimsel çalışmalara bakıldığında da Dünya'da yenilenebilir enerji ile ilgili en çok Mühendislik alanınca çalışmalar yapılmıştır.

Genel olarak bakıldığında son yıllarda ülkemizde yenilenebilir enerji alanına yatırımlar artmış olsa da Dünya ölçeğinde istenen seviyede olmadığımız görülmektedir. Ülkemizdeki patent sayılarını Dünya'daki sayılarla karşılaştırdığımızda, Dünya'nın oldukça gerisinde olduğumuzu ve bu alana ağırlık vermesi gerektiği sonucunu çıkarabiliriz. Ayrıca, ülkemizde daha çok rüzgar alanında patent alındığ 1 görülmekte olup diğer yenilenebilir enerji kaynaklarına da ağırlık verilmesi gerektiği sonucunu çıkarabiliriz.

\section{Teşekkür}

Bu çalışmada, Orbit Innovation yazılımının kullanılmasını sağlayan Questel şirketine teşekkür ederiz.

\section{Kaynakça}

Aggarwal, S., \& Chandra, A. (2021). An Insight into Patent Landscape Analysis of Plant Stem Cells. World Patent Information.

Hua, Z., Yang, J., \& Coulibaly, S. (2006). Integration TRIZ with problem-solving tools: a literature review from 1995 to 2006. International Journal of Business Innovation and Research, 1, 111-128.

Jun, S. (2015). Patent Statistics for Technology Analysis. International Journal of Software Engineering and its Applications, 9, 155-164.

Jun, S., \& Lee, S.-J. (2013). Patent Analysis Using Bayesian Network Models.

Jun, S., \& Park, S. (2012). New Technology Management Using Time Series Regression and Clustering.

Kabataş, K., \& Akgün, A. (2020). Technology Forecasting. Bilge International Journal of Social Research, 65-70.

Kaya, H. İ., \& Bayraktar, Y. (2019). Hukuki Düzenlemeler, Politika Destekleri ve Mali Teşviklerin Yenilenebilir Enerjinin Gelişimindeki Rolü: Çin Halk Cumhuriyeti Örneği. C.Ü. İktisadi ve İdari Bilimler Dergisi, 20(1).

Kaya, K., \& Koç, E. (2015). Enerji Üretim Santralleri Maliyet Analizi. Mühendis ve Makina, 61-68.

Liang, Y., Tan, R., \& Ma, J. (2008). Patent analysis with text mining for TRIZ. 2008 4th IEEE International Conference on Management of Innovation and Technology, 1147-1151.

Liimatainen, H., Kallionpää, E., Pöllänen, M., Stenholm, P., Tapio, P., \& McKinnon, A. C. (2014). Decarbonizing road freight in the future - Detailed scenarios of the carbon emissions of Finnish road freight transport in 2030 using a Delphi method approach. Technological Forecasting and Social Change, 81, 177-191.

Mitchell, V. (1992). Using Delphi to Forecast in New Technology Industries. Marketing Intelligence \& Planning, 10, 4-9.

Renaldi, R., Miranda, N. D., Khosla, R., \& McCulloch, M. (2021). Patent Landscape of not-in-kind Active Cooling Technologies Between 1998 and 2017. Journal of Cleaner
Production.

Rowe , G., \& Wright, G. (2001). Expert Opinions in Forecasting: The Role of the Delphi Technique.

Tubitak Ar-Ge Harcamaları, (2021, 9 Ekim), Erişim Adresi: https://www.tubitak.gov.tr/tubitak_content_files/BTYPD/ist atistikler/BTY15.pdf

Tunç, H. (2008). Bir Yenilik Göstergesi Olarak Patent Ve Türkiye Patent Performansı, Süleyman Demirel Üniversitesi Sosyal Bilimler Enstitüsü, Yüksek Lisans Tezi, Isparta.

Woudenberg, F. (1991). An Evaluation of Delphi. Technological Forecasting and Social Change, 40(131-150). 